Gut, 1975, 16, 871-875

\title{
Antibodies to Escherichia coli in chronic liver diseases
}

\author{
A. E. SIMJEE ${ }^{1}$, J. M. T. HAMILTON-MILLER, H. C. THOMAS, W. BRUMFITT, \\ AND SHEILA SHERLOCK ${ }^{2}$
}

From the Departments of Medical Microbiology and Medicine, The Royal Free Hospital, London

SUMMARY Patients with chronic active hepatitis or alcoholic cirrhosis have serum antibodies to many more serotypes of Escherichia coli than do patients with primary biliary cirrhosis or cryptogenic cirrhosis, or normal controls. They also have antibodies against more serotypes than cirrhotic patients with a portacaval shunt. These observations suggest that factors other than shunting of blood away from the liver are responsible for the increased range of antibodies. These factors are discussed. There was no correlation between the number of serotypes to which antibodies were present and the serum immunoglobulin concentration. In three patients, each with chronic active hepatitis, the antibodies were predominantly of the IgM class, while the elevation of globulin in general was mainly due to increased IgG and IgA levels. Antibodies to Escherichia coli, therefore, probably contribute only a small part of the increased globulin levels found in patients with chronic liver disease.

The cause of the hypergammaglobulinaemia of liver diseases is not known. There are several possible mechanisms, and these have been reviewed recently (Triger and Wright, 1973). One group of antibodies found to be abnormal both quantitatively and qualitatively in chronic liver disease is that to intestinal organisms, including the $O$ antigen of Escherichia coli. Patients with cirrhosis have antibodies to a greater number of Esch.coli serotypes than do normal controls (Bjørneboe et al., 1972; Prytz et al., 1973). This was especially marked in patients with surgical portacaval shunts or alcoholic cirrhosis. Patients with chronic active hepatitis also have greater antibody titres to Esch.coli $\mathrm{O}$ antigens than patients with other chronic liver disease (Triger et al., 1972). Rats with surgically induced portacaval shunts have increased numbers of antibodies to Esch.coli and also increased total $\gamma$-globulin levels (Keraan et al., 1974). These observations have led to the suggestion that the increased antibodies are directed towards Esch.coli serotypes present in the patients' intestines. However, the techniques used by two groups (Triger et al., 1972;

\footnotetext{
'Present address: King Edward VIIIth Hospital, Natal, South Africa. Address for reprint requests: Department of Medicine, Royal Free Hospital, Pond Street, Hampstead, London NW3 2QG.

Received for publication 3 September 1975.
}

Keraan et al., 1974) did not enable the identification of the range of Esch.coli serotypes against which the antibodies reacted; neither was it possible to determine if these serotypes were present in the subjects under study.

The finding that antibodies to Salmonella spp. are increased in patients with chronic active liver disease (Protell et al., 1971) suggests that this might not be the complete story. We decided to investigate this problem further by looking for individual antibodies to a large group of specific Esch.coli $\mathrm{O}$ serotypes.

The immunoglobulin class of the antibodies was investigated in order to determine whether these antibodies contribute to the altered immunoglobulin concentrations found in patients with liver disease.

\section{Methods}

\section{PATIENTS}

Table 1 shows the disease groups studied, the number of subjects in each group and their age ranges. Diagnosis in nearly all the cases was made by liver biopsy, supported by clinical, biochemical, and immunological findings.

Three of the patients with chronic active hepatitis were positive for hepatitis B antigen. Seven had histological evidence of cirrhosis; 10 were 


\begin{tabular}{lcll}
\hline Diagnosis & $\begin{array}{l}\text { Subjects } \\
(\text { no. })\end{array}$ & $\begin{array}{l}\text { Age range } \\
(\boldsymbol{y r})\end{array}$ & Mean \\
\hline Active chronic hepatitis & 12 & $14-69$ & 45 \\
Alcoholic cirrhosis & 6 & $42-66$ & 57 \\
Primary biliary cirrhosis & 9 & $44-71$ & 58 \\
Cryptogenic cirrhosis & 8 & $31-71$ & 59 \\
Portacaval shunt & 8 & $31-71$ & 57 \\
Healthy controls & 9 & $23-45$ & 29 \\
\hline
\end{tabular}

Table 1 Subjects studied

receiving prednisolone treatment during the study.

The patients on whom portacaval shunting had been performed had inactive cirrhosis with severe portal hypertension and a history of at least one episode of haemorrhage from oesophageal varices.

The nine controls were selected from healthy laboratory staff. None was subjected to liver biopsy but liver function tests were all normal.

Blood samples taken from the subjects were allowed to clot and the serum was separated. Sera were stored at $-20^{\circ} \mathrm{C}$.

\section{Techniques}

\section{TECHNIQUES}

Agglutination tests One hundred and fifty different O serotypes of Esch.coli were obtained from DrK.A. Bettelheim, St Bartholomew's Hospital, London. These organisms were inoculated into $10 \mathrm{ml}$ amounts of nutrient broth, incubated overnight at $37^{\circ} \mathrm{C}$, centrifuged, the supernatant fraction discarded, and the deposit of bacteria resuspended in $10 \mathrm{ml}$ $0.85 \%$ saline. The suspensions were steamed at $100^{\circ} \mathrm{C}$ for two hours, and each was diluted to an optical density of between 0.4 and 0.5 at $540 \mathrm{~nm}$. Thiomersal was added, to a final concentration of $1 / 10,000$ as preservative. These antigens were stored in plastic $25 \mu \mathrm{l}$ dispensing bottles at $4^{\circ}$.

All sera were screened for agglutinating antibodies to the 150 serotypes of Esch.coli. Sera were diluted to $1 / 80$ in saline and tested in Microtiter U-plates against all the antigen suspensions, using $25 \mu \mathrm{l}$ each of antigen suspension and diluted serum. Plates were sealed and incubated overnight at $37^{\circ}$. All sera for which positive or doubtful results were obtained were then retested by the tube dilution technique as described by Percival et al. (1964). Each tube contained $0.1 \mathrm{ml}$ each of serum (diluted in the range $1 / 80$ to $1 / 5120$ ) and antigen suspension. A 'positive' test in the context of the present investigation was taken as one giving a titre of at least $1 / 320$.

Both the initial screening test and the tube dilution test were read in duplicate by independent observers.
Treatment of sera with 2-mercaptoethanol Three sera were treated, by previously described methods (Kim et al., 1964; Sahiar and Schwartz, 1965), and agglutination tests repeated with reacting antigens.

Serum immunoglobulin concentrations Serum IgG and IgA were determined on the Autoanalyser (Specific Protein Analyser: Technicon Instruments Co., Ltd., Basingstoke, Hants). IgM was estimated by the method of Mancini et al. (1965).

\section{Results}

NUMBER OF SEROTYPES TO WHICH ANTIBODIES ARE PRESENT IN DIFFERENT GROUPS

The Figure shows the number of serotypes to which antibodies are present in individual patients, grouped into disease classes. It is clear that two groupspatients with chronic active hepatitis or alcoholic cirrhosis-have substantially greater numbers of antibodies than do any of the other groups separately. These differences were significant by Wilcoxon's two sample rank test-the Mann Whitney test $(\mathrm{P}<0.05)$.

CORRELATION OF IMMUNOGLOBULIN LEVELS WITH NUMBER OF SEROTYPES TO WHICH ANTIBODIES ARE PRESENT

Immunoglobulin levels in the various groups are shown in Table 2.

There was no correlation between the number of antibodies and levels of immunoglobulins either individually (IgG, IgA or IgM) or in sum.

\section{NATURE OF ANTIBODY}

In three of the patients in whom antibodies to a large number of serotypes were found immunoglobulin classification was attempted by means of 2-mercaptoethanol treatment of the serum; such treatment removes IgM (and probably IgA). In all three cases, titres dropped markedly after such treatment; a representative result is shown in Table 3.

Independent experiments by one of us (H. C. T.), using sera from other patients with either chronic active hepatitis or alcoholic cirrhosis, were carried out. Sera were fractionated using sucrose density gradients. Agglutinating activity against Esch.coli was confined to those fractions containing IgM. Both direct and indirect agglutination tests (the latter carried out using a rabbit anti-human globulin) were used in testing these fractions.

\section{Discussion}

The Kuppfer cells of the healthy liver are the chief site of removal of antigenic material (Braude et al., 


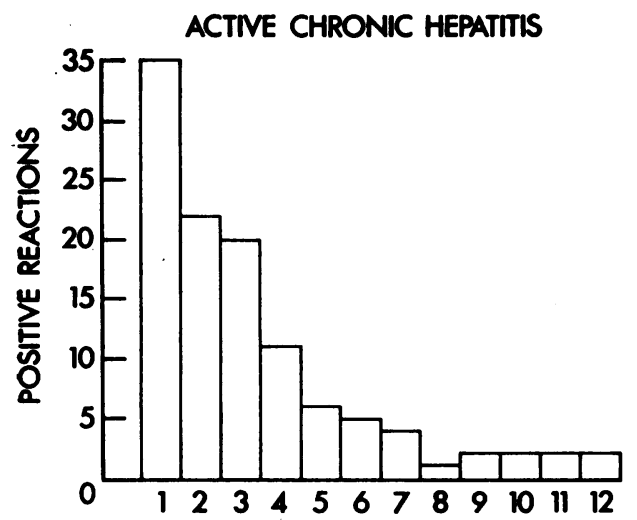

ALCOHOLIC CIRRHOSIS

PRIMARY BILIARY CIRRHOSIS
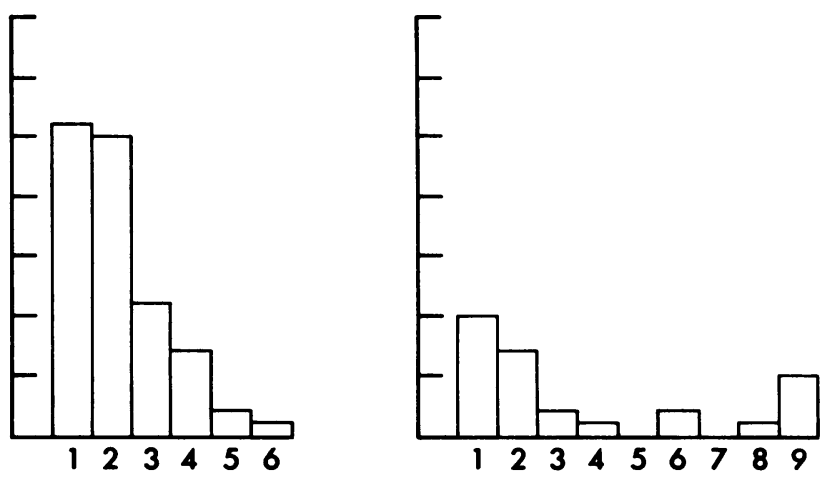

\section{PATIENT NUMBERS}

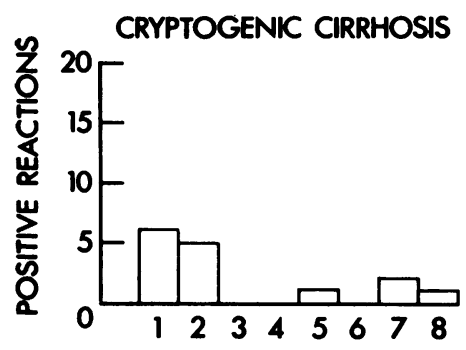

PORTACAVAL SHUNTS

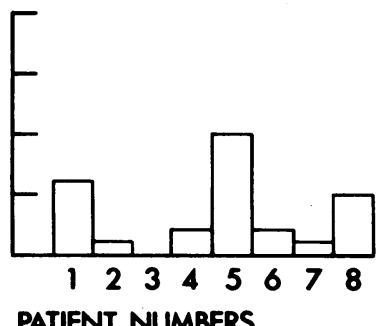

CONTROLS

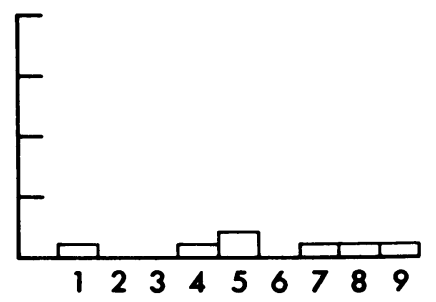

Figure Results in five groups of different patients and a control group. Each column shows number of positive results found when agglutination tests were carried out against 150 specific $O$ serotypes.

\begin{tabular}{|c|c|c|c|c|}
\hline \multirow[t]{2}{*}{ Diagnosis } & \multicolumn{4}{|c|}{$\begin{array}{l}\text { Range (and mean) of immunoglobulin levels } \\
\text { (mg/dl) }\end{array}$} \\
\hline & $I g G$ & $\operatorname{Ig} M$ & $\operatorname{IgA}$ & Totals \\
\hline $\begin{array}{l}\text { Active chronic } \\
\text { hepatitis }\end{array}$ & $\begin{array}{l}1240-3300 \\
(2195)\end{array}$ & $\begin{array}{l}171-510 \\
(284)\end{array}$ & $\begin{array}{l}150-1245 \\
(371)\end{array}$ & $\begin{array}{l}1561-5055 \\
(2840)\end{array}$ \\
\hline Alcoholic cirrhosis & $\begin{array}{l}800-1710 \\
(1248)\end{array}$ & $\begin{array}{l}153-1000 \\
(396)\end{array}$ & $\begin{array}{l}162-765 \\
(555)\end{array}$ & $\begin{array}{l}1985-2628 \\
(2187)\end{array}$ \\
\hline $\begin{array}{l}\text { Primary biliary } \\
\text { cirrhosis }\end{array}$ & $\begin{array}{l}1280-3080 \\
(2086)\end{array}$ & $\begin{array}{l}282-846 \\
(489)\end{array}$ & $\begin{array}{l}172-856 \\
(369)\end{array}$ & $\begin{array}{l}1870-4256 \\
(2944)\end{array}$ \\
\hline Cryptogenic cirrhosis & $\begin{array}{l}672-4350 \\
(2226)\end{array}$ & $\begin{array}{l}60-740 \\
(260)\end{array}$ & $\begin{array}{l}276-1170 \\
(470)\end{array}$ & $\begin{array}{l}1008-5136 \\
(3064)\end{array}$ \\
\hline Portacaval shunts & $\begin{array}{l}672-2760 \\
(1959)\end{array}$ & $\begin{array}{l}60-470 \\
(274)\end{array}$ & $\begin{array}{l}276-1117 \\
(470)\end{array}$ & $\begin{array}{l}1008-3642 \\
(2703)\end{array}$ \\
\hline Normal values & $800-1100$ & $50-190$ & $140-420$ & \\
\hline
\end{tabular}

Table 2 Immunoglobulin levels in groups studied

1955; Thomas et al., 1973) and these cells render antigen relatively non-immunogenic (Cantor and Dumont, 1967; Inchley, 1969). In cirrhosis of the liver shunting of blood away from the Kuppfer cells decreases their efficiency in this respect. Patients

\begin{tabular}{lll}
\hline Esch.coli serotype & Titre & \\
\cline { 2 - 3 } & Untreated & $\begin{array}{c}\text { After treatment with } \\
2-\text {-mercaptoehtanol }\end{array}$ \\
\hline O1 & $1 / 320$ & $<1 / 10$ \\
O2 & $1 / 1280$ & $<1 / 10$ \\
O3 & $1 / 320$ & $1 / 40$ \\
O4 & $1 / 320$ & $<1 / 10$ \\
O5 & $1 / 1280$ & $1 / 40$ \\
O8 & $1 / 1280$ & $<1 / 10$ \\
O10 & $1 / 640$ & $<1 / 10$ \\
O12 & $1 / 320$ & $1 / 80$ \\
O13 & $1 / 1280$ & $1 / 40$ \\
O18 & $1 / 640$ & $1 / 80$ \\
\hline
\end{tabular}

Table 3 Reduction of bacterial agglutinating titre after treatment with 2-mercaptoethanol in a patient with chronic active hepatitis

with cirrhosis have been observed to have increased antibody titres to the lipopolysaccharide (O antigen) of the Enterobacteriaceae. This observation has led some workers to suggest that this is due to the $\mathrm{O}$ antigen by-passing the Kuppfer cells and thereby 
escaping inactivation (Bjørneboe et al., 1972; Triger et al., 1972). This received further support from two groups of workers. First, Bjørneboe et al. (1972) found that there was a qualitative increase in antibodies to the $\mathbf{O}$ antigen in cirrhotics with portacaval shunts. Secondly (Keraan et al., 1974), in rats subjected to end-to-side portacaval shunts higher titres of antibodies to the $\mathrm{O}$ antigen were found than in animals which had had sham operations without the production of a shunt.

Our findings provide new information, by demonstrating a quantitative and qualitative difference in antibody response between alcoholic cirrhosis and chronic active hepatitis on the one hand, and, on the other hand, patients with different liver diseases whether or not a portacaval shunt was present. In these patients not only was the antibody titre lower, but the number of specific $\mathrm{O}$ antibodies was considerably less. Our findings could be explained by one of two hypotheses.

The first hypothesis suggests that the increased response is a specific one. It is well known that patients who are admitted to hospital show changes in the $O$ serotypes of Esch.coli present in the bowel. The patients that we studied had all been admitted to hospital several times. In these circumstances, the gut flora frequently change and strains usually regarded as being uncommon in the bowel become predominant (Grüneberg et al., 1968; Cooke et al., 1969). Shunting is unlikely to be greater in the patients with chronic active hepatitis and alcoholic cirrhosis. Hence, there may be more important mechanisms, operating in conjunction with shunting of blood away from the Kuppfer cells. One such factor could be abnormal Kuppfer cell function, resulting in failure of these cells to remove antigens reaching them. It has been shown in animals that phagocytosis and intracellular destruction of bacteria is impaired in the alcoholic (Louria, 1963). Although impaired phagocytic function has not been shown in chronic active hepatitis, it has been suggested that when hepatocellular necrosis is present the Kuppfer cells are engaged in the phagocytosis of the necrotic tissue, with consequent reduced ability to remove exogenous antigen (Thomas et al., 1973). This hypothesis is difficult to test for technical reasons. As we have shown elsewhere (Grüneberg et al., 1968) a prohibitive number of tests involving faecal specimens, bacterial colonies and specific antisera would have to be carried out in order to provide a statistically significant result. Furthermore, the problem arises that, with poor Kuppfer cell function as distinct from shunting, organisms in such small numbers as to be undetectable even by elaborate bacteriological techniques could, nevertheless, elicit an antibody response.
The second possibility is that the increased response is the result of an anamnestic process (Thomas et al., 1973). The endotoxin moiety of lipopolysaccharide could have this effect, as it has been shown to be a B-cell mitogen (Möller et al., 1973). We suggest that impaired Kuppfer cell function results in persistence of lipopolysaccharide which activates the memory cells of the B-lymphocyte group, so that antibodies to several immunochemically distinct serotypes are produced. In addition, the adjuvant properties of lipopolysaccharide could well explain the increased quantitative response. The production of autoantibodies, such as smooth muscle antibodies and anti-nuclear factor, in chronic active hepatitis might also be related to the presence of endotoxaemia; since it has been shown in rabbits that autoantibodies, such as rheumatoid factor, can be produced by the repeated injection of Esch.coli (Christian et al., 1965). The concentration of endotoxin necessary for this is probably lower than the $5 \mathrm{ng} / \mathrm{ml}$ reported in plasma and positively correlated with mortality in patients with acute liver failure (Wilkinson et al., 1974).

The greater incidence of autoantibodies in patients with chronic active hepatitis than in the alcoholic group (Doniach et al., 1966) needs further explanation, which may be forthcoming in terms of $T$ cell function. The patients with chronic active hepatitis have a more severe impairment of $T$ cell function than do alcoholic hepatitis patients (Thomas et al., unpublished results) and it is established (Allison, 1971) that the maintenance of tolerance is dependent on normal $\mathrm{T}$ cell function. Endotoxin may therefore result in a break in tolerance to self antigens in patients with active chronic hepatitis but not in alcoholic liver disease patients whose $\mathbf{T}$ cell function is less impaired.

It has been postulated that the increased antibodies to Esch.coli $\mathrm{O}$ antigens may play an important role in the hypergammaglobulinaemia of liver diseases. This has support from experiments in originally germ-free animals (Sell, 1964; Sell and Fahey, 1964), where the development of $\gamma$-globulins was related to the extent to which bacteria were allowed to colonize the gut. Esch.coli antibodies in our patients were mainly IgM, and so are unlikely to play an important part in the observed increase in IgG and IgA. That this is the case was further suggested by our finding that there was no correlation between the number of serotypes to which antibody was found and the immunoglobulin levels, including IgM. Antibodies directed toward other bacterial antigens, perhaps derived from the intestine, may be responsible for this hyperglobulinaemia.

The presence of antibodies does not protect these 
patients from infection by their own gut flora. Therefore, either antibodies to the $\mathrm{O}$ antigens of Esch.coli are not protective (as in urinary tract infections), or other factors, such as deficiencies in the mononuclear phagocytic system in these patients, are involved.

A. E. Simjee was supported by grants from $\mathrm{Mr}$ A. J. Burton, the South African Medical Research Council, and the R. K. Khan Trust. We are grateful to Mrs Italia Franklin for practical advice and assistance with the aggutination tests, and Drs J. G. Howard and $\mathbf{J}$. Kosmidis for valuable discussions.

\section{References}

Allison, A. C. (1971). Unresponsiveness to self antigens. Lancet, 2, 1401-1403.

Bjørneboe, M., Prytz, H., and Ørskov, F. (1972). Antibodies to intestinal microbes in serum of patients with cirrhosis of the liver. Lancet, 1, 58-60.

Braude, A. I., Carey, F. J., and Zalesky, M. (1955). Studies with radioactive endotoxin. 2. Correlation of physiologic effects with distribution of radioactivity in rabbits injected with lethal doses of Escherichia coli endotoxin labelled with radioactive sodium chromate. Journal of Clinical Investigation, 34, 858-866.

Cantor, H. M., and Dumont, A. E.(1967). Hepatic suppression of sensitization to antigen absorbed into the portal system. Nature, 215, 744-745.

Christian, C. L., Abruzzo, J. L., De Simone, A. R., and Howes, E. L. (1965). Studies in hyperimmunization. Annals of the New York Academy of Sciences, 124, 143-146.

Cooke, E. M., Ewins, S., and Shotter, R. A. (1969). Changing faecal population of Escherichia coli in hospital medical patients. British Medical Journal, 4, 593-595.

Doniach, D., Roitt, I. M., Walker, J. G., and Sherlock, S. (1966). Tissue antibodies in primary biliary cirrhosis, active chronic (lupoid) hepatitis, cryptogenic cirrhosis and other liver diseases, and the clinical implications. Clinical and Experimental Immunology, 1, 237-262.

Grüneberg, R. N., Leigh, D. A., and Brumfitt, W. (1968). Escherichia coli serotypes in urinary tract infection: studies in domiciliary, ante-natal and hospital practice. In Urinary Tract Infection, pp. 68-79. Edited by F. A. O'Grady and W. Brumfitt. Oxford University Press: London.
Inchley, C. J. (1969). The activity of mouse Kuppfer cells following intravenous injection of $\mathrm{T} 4$ bacteriophage. Clinical and Experimental Immunology, 5, 173-187.

Keraan, M., Meyers, O. L., Engelbrecht, G. H. C., Hickman, R., Saunders, S. J., and Terblanche, J. (1974). Increased serum immunoglobulin levels following portacaval shunt in the normal rat. Gut, 15, 468-472.

Kim, Y. B., Bradley, S. G., and Watson, D. W. (1964). Characterization of early $19 \mathrm{~S}$ and late $7 \mathrm{~S}$ immunoglobulins in the mouse. Journal of Immunology, 93, 798-806.

Louria, D. B. (1963). Susceptibility to infection during experimental alcoholic intoxication. Transactions of the Association of American Physicians, 76, 102-112.

Mancini, G., Carbonara, A. O., and Heremans, J. F. (1965). Immunochemical quantitation of antigens by single radial immunodiffusion. Immunochemistry, 2, 235-254.

Möller, G., Olof, S., and Andersson, J. (1973). Immunogenicity, tolerogenicity and mitogenicity of lipopolysaccharides. Journal of Infectious Disease, 128, suppl. S52-55.

Percival, A., Brumfitt, W., and De Louvois, J. (1964). Serum-antibody levels as an indication of clinically inapparent pyelonephritis. Lancet, 2, 1027-1033.

Prytz, H., Bjørneboe, M., Ørskov, F., and Hilden, M. (1973). Antibodies to Escherichia coli in alcoholic and nonalcoholic patients with cirrhosis of the liver or fatty liver. Scandinavian Journal of Gastroenterology, 8, 433-438.

Protell, R. L., Soloway, R. D., Martin, W. J., Schoenfield, L. J., and Summerskill, W. H. J. (1971). Anti-salmonella agglutinins in chronic active liver disease. Lancet, 2, 330-332.

Sahiar, K., and Schwartz, R. S. (1965). Immunoglobulin sequence: 1. Arrest by 6-mercaptopurine and restitution by antibody, antigen or splenectomy. Journal of Immunolog $y, 95,345-354$.

Sell, S. (1964). Immunoglobulins of the germ-free guinea pig. Journal of Immunology, 93, 122-131.

Sell, S., and Fahey, J. L. (1964). Relationship between $\gamma$-globulin metabolism and low serum $\gamma$-globulin in germfree mice. Journal of Immunology, 93, 81-87.

Thomas, H. C., McSween, R. N. M., and White, R. G. (1973). Role of the liver in controlling the immunogenicity of commensal bacteria in the gut. Lancet, 1, 1288-1291.

Triger, D. R., Alp, M. H., and Wright, R. (1972). Bacterial and dietary antibodies in liver disease. Lancet, 1, 60-63.

Triger, D. R., and Wright, R. (1973). Hyperglobulinaemia in liver disease. Lancet, 1, 1494-1496.

Wilkinson, S. P., Arroyo, V., Gazzard, B. G., Moodie, H., and Williams, R. (1974). Relation of renal impairment and haemorrhagic diathesis to endotoxaemia in fulminant hepatic failure. Lancet, 1, 521-524. 